STUDIA POLONIJNE

T. 41. LUBLIN 2020

DOI: http://doi.org/10.18290/sp2041-15

MATEUSZ SZAST

\title{
THE CONTEMPORARY MIGRANT FAMILY IN THE EYES OF A POLE IN IRELAND
}

\begin{abstract}
INTRODUCTION
The aim of the article is to show, on the basis of pilot studies (free-form interviews), the essence of a modern migrant family, with particular emphasis on relationships between family members, their social roles, the implementation of family functions as part of a broadly understood migration and adaptation to new living conditions of migrants.

Ireland, referred to as the "green island," is a small country that still enjoys considerable interest of migrants of Polish origin. Ireland's population increased rapidly by about 1.9 million over 60 years from 2,898,264 in 1956 to 4,761,865 in 2016. In April 2016, Ireland was inhabited by 535,475 incoming migrants - a 1.6\% increase from 544,3571 in 2011. ${ }^{1}$ Over 25 years, the number of foreign-born people living in Ireland increased from $6 \%$ in 1991 to $17.3 \%$ in 2011 - 810,406 residents were born outside Ireland. ${ }^{2}$ For several years now, Poles have constituted the largest group among the incoming population, with 122,515 in $2016 .^{3}$ In 2006, 63,276 citizens of Polish origin were recorded, in 2011 this number was 122,585 according to calculations of the Irish Statistical Office, and 122,515 people in $2016 .{ }^{4}$
\end{abstract}

Mateusz Szast, PhD - works at the Institute of Philosophy and Sociology at the Pedagogical University of Cracow; e-mail: szastmateusz@gmail.com. ORCID: https:// orcid.org/0000-0001-56776471.

${ }^{1}$ K. Lisenkova, I. Mosca, R.E. Wright, Ireland and Scotland: Converging or Diverging Demography?, "Scottish Affairs," Vol. 64, No. 1, 2008, pp. 18-36.

${ }^{2}$ Ł. KurmeK, Migration and Fertility. Polish Migrant Families in Ireland and Non-Migrant Families in Poland: A Comparison of Fertility Plans and Behaviour, "Central and Eastern European Migration Review," Vol. 6, No. 2, 2017, pp. 5-30, Published online: 18 October 2017, p. 7.

${ }^{3}$ Central Statistics Office, Ten nationalities account for $70 \%$ of Non-Irish Nationals, Press Statement, Preasráiteas 18 September 2018.

${ }^{4}$ Central Statistics Office, Census 2016 - Non-Irish Nationalities Living in Ireland, Marital Status, https://www.cso.ie/en/releasesandpublications/ep/p-cpnin/cpnin/polish (see: February 28, 2020). 
Statistical surveys carried out in Ireland show that half (51.5\%) of all households in the country have some form of debt, while in comparison with $56.8 \%$ in 2013 , the average value of debt for households has decreased by more than $€ 20,000$ since 2013 , from $€ 63,000$ to $€ 42,300 .{ }^{5}$ Ireland is an attractive country for migrants due to the numerous possibilities of assistance and support for its citizens - including the migrant population. ${ }^{6}$

Irish people are characterized by a love of music, a strong sense of Irishness, Celtic culture, language, dance, Irish literature, writers like Oscar Wilde and James Joyce or sailing traditions. ${ }^{7}$ Poles have also developed a peculiar canon of culture and religiousness centred around tradition and language, family life, passion for beer, regionalism, traditions - these are the features that have brought nations closer together. Both countries are connected by cultural significance with such figures as Kazimierz Markievicz and John Paul II. The Irish Polish Society was established in preparation for the Pope's visit to the island at a time when about 350 Poles lived there. ${ }^{8}$ They established The Irish Polish Society. ${ }^{9}$

\section{MIGRATION STRATEGIES OF POLES TO IRELAND}

Modern migration, also called new or economic migration, is a mass phenomenon. There may be many reasons for leaving the country, just as there are many migration strategies (the migration plan), as described by Anthony Richmond in 1992, distinguishing structural factors such as the economic crisis, unemployment, social insecurity, depopulation of rural areas and urbanisation. ${ }^{10}$ They may have numerous consequences, such as adaptation of immigrants, the creation of homogeneous groups, dual citizenship and the transnational character of civil society ${ }^{11}$ - living simultaneously in two dimensions, in two cultural spaces, in two worlds,

5 Central Statistics Office, Household Finance and Consumption Survey (HFCS) 2018, Press Statement Preasráiteas 30 January 2020.

${ }^{6}$ CÉAD Míle Fállte, Ireland in Brief. A general overview of Ireland's political, economic and cultural life, Iveagh House, headquarters of the Department of Foreign Affairs and Trade, Dublin 2013, p. 29.

7 M. ua SÉAghdHA, The Story of Ireland a Bridge between Celtic and Modern, America and Europe, Published by: Nakladatelství Bridge $\odot$, Bridge Polska, Prague 2007, pp. 22-30.

${ }^{8}$ S. Hoffman, Ireland and Poland: A History of Solidarity, www.krakowpost.com/8908/2015/03/ ireland-and-poland-a-history-of-solidarity (see: March 17, 2015).

9 About Us, http://irishpolishsociety.ie/about-us/ (see: February 28, 2020).

10 A. Richmond, Immigration and Structural Change: The Canadian Experience 1992, 19711986, "International Migration Review," Vol. 26, No. 4, 1992, p. 1211.

11 T. FAIST, The Volume and Dynamics of International Migration and Transnational Social Spaces, Oxford 2000, p. 15. 
the so-called old and new. ${ }^{12}$ Immigrants started to function well in both places, although not permanently in any of them. They built a transnational social space bridge. ${ }^{13}$ Alicja Bobek's research proved that the majority of Poles who arrived in Ireland (especially Dublin) after 2004 migrated in a chain fashion. ${ }^{14}$

Łukasz Klimek's research (2014) revealed delaying childbearing and a decrease in the number of families with children among migrant families, and that migrant parents have more children than the ones living in Poland. ${ }^{15}$ Polish families showed family reunification in Ireland. In 2011, Ireland was inhabited by 32,642 more women born in Poland compared to five years earlier. In 2014, there were 55,584 Polish women and 59,609 men born in Poland - a noticeable contrast compared to 2006 , when the male to female ratio was $2: 1$. This strong rate of family reunification among the Polish community in Ireland is highlighted three more times by the number of children born in Poland. ${ }^{16}$

Migration also has its negative consequences for families, as Anna White studied, e.g. greater pain and family breakdown, everyday consumption in Poland. ${ }^{17}$ Stephen Castles calls them connections, nodes. The simplest node is the human individual, which can be connected with other individuals or groups directly or indirectly. However, social groups are separated from social networks by the following difference: networks are characterised by weak bonds and groups by strong ones. ${ }^{18}$ The modern world is increasingly a world of dispersed diasporas and social networks, which in turn constitute a "vehicle of social support"19 relevant to the analysis of push and pull factors. ${ }^{20}$

12 D. Praszalowicz, Polskie studia na temat migracji kobiet: wybrane perspektywy teoretyczne $i$ wyniki badań, in: Migracje kobiet. Perspektywa wielowymiarowa, ed. K. Slany, Kraków 2008, pp. 51-62, p. 54.

13 M. Łukasiuk, Obcy w mieście. Migracja do współczesnej Warszawy, Warszawa 2007, p. 101.

${ }^{14}$ A. Boвeк, Polscy migranci $w$ Irlandii. Rola sieci spotecznych $w$ procesie migracyjnym oraz w ksztaltowaniu się społeczności etnicznej, "Studia Humanistyczne AGH,” Vol. 8, 2010, p. 60.

${ }^{15}$ Ł. KuIMeK, Migration and Fertility. Polish Migrant Families in Ireland and Non-Migrant Families in Poland, pp. 5-30, p. 6.

${ }^{16}$ S. O'CARroll, Polish families reuniting in Ireland as they become largest non-Irish grouphttps, ://www.thejournal.ie/polish-families-reuniting-in-ireland-as-they-become-largest-non-irish-group400769-Mar2012/ (see: February 28, 2020).

${ }^{17}$ A. White, Polish Circular Migration and Marginality: A Livelihood Strategy Approach, “Studia Migracyjne - Przegląd Polonijny,” Vol. 1, 2016, p. 155 (pp. 151-164).

${ }^{18}$ S. Castles, H. de HaAs, Mark J. Miller, The Age of Migration International Population Movements in the Modern World Fifth Edition, London 2014, p. 40.

${ }_{19}$ M. Łukasiuk, M. Jedokimow, Niedom. Socjologiczna monografia mieszkań migracyjnych, Warszawa 2012, p. 117.

${ }^{20}$ E. LeE, A Theory of migration, "Demography,” Vol. 3, 1966, pp. 16, 54. 


\section{RESEARCH ASSUMPTIONS}

The research was conducted among Polish migrants living in Ireland. Freeform interviews were conducted from 30 July to 15 August 2019 among 15 people, where five representatives were selected: from complete Polish families living in Ireland (these were nuclear families consisting of parents with one to three children), families temporarily separated (married or unmarried) living in Ireland without their families and unmarried people. The research was unrepresentative because of its structure and method. It was conducted among Poles in Ireland living in the towns of Virginia and Ballyjamesduff and 15 interviews were qualified for final analysis, transcribed and strictly documented, taking into account methodological standards used in social sciences.

Tabela 1. Data of persons taking part in free-form interviews

\begin{tabular}{|r|r|l|c|l|}
\hline Lp. & Age & Gender & Length of stay in Ireland & \multicolumn{1}{|c|}{ Function } \\
\hline 1. & 34 & Male & 10 & Grocery store shop assistant \\
\hline 2. & 35 & Male & 12 & Sales representative \\
\hline 3. & 61 & Male & 15 & Shift manager - quality control \\
\hline 4. & 38 & Female & 13 & Grocery store shop assistant \\
\hline 5. & 23 & Female & 13 & Student \\
\hline 6. & 39 & Male & 9 & Blue-collar worker \\
\hline 7. & 26 & Male & 6 & Blue-collar worker \\
\hline 8. & 50 & Male & 14 & Taxi driver \\
\hline 9. & 33 & Female & 8 & White-collar worker \\
\hline 10 & 44 & Female & 10 & Translator \\
\hline 11. & 36 & Female & 11 & Nurse \\
\hline 12. & 35 & Female & 7 & Housewife \\
\hline 13. & 29 & Female & 6 & Housewife \\
\hline 14. & 40 & Male & 14 & Private entrepreneur \\
\hline 15. & 41 & Female & 3 & Housewife / hairdresser \\
\hline
\end{tabular}

Source: own materials

\section{MIGRATION FAMILY IN THE OPINION OF THE RESPONDENTS}

Respondents participating in the survey confirm that they see changes in the area of functioning of families in Ireland or families abroad. One of the respondents even stated strongly: "Of course the changes are visible." Poles who have been coming to Ireland since 2004 have found a completely different world of functioning of a man from a mono-national state to a multicultural state, where greater anonymity as well 
as respect for privacy are perceived. People feel more at ease, because in Ireland, Poles, unmarried people, live a different life than in Poland - they are free, they feel easy and can do what they want; for example, they go to discos, parties, live life to the full - provided they have the time for it. They can afford entertainment, of which they also have in abundance, but less money. The functioning of whole families is completely different - they live a normal life, have everyday worries (school, health, relationship problems). However, they can be certain that this country will not leave them without help in a difficult situation (they call it socjal), which in the case of Poland has recently been implemented. Families buy houses and have a high standard of living. As one respondent mentioned, in Poland people squeeze into cramped flats - in cubicles (Kazimierz, 14 years in Ireland). In Ireland there are completely different living and development conditions as there are generally few flats, at least in a given region, most houses are rented or sublet in yards of different sizes, which involves a lot of space, streets are convenient, there are, entertainment parks for children, and in Poland? Friends tell us that a flat in Kraków is an imposible dream and a small flat in a town in the middle of nowhere costs 150-200 thousand. In Ireland I will earn it in 5 years - in Poland 40 years of credit for 40 meters? Horror. Despite the fact that the situation in Poland has changed a little bit for the better - higher salaries, child allowances as in Ireland, high benefits, the prices have gone up too much. Single people spend their free time according to their own preferences, using services, trips, sports, etc. In turn, people from families or temporarily separated families miss each other, send parcels by courier, write, call on the Internet or bring loved ones for holidays, they go together to Poland. I spend about 3 months together with my family each year. You have to organize your life in such a way as to make it work - said Wojciech, who has lived in Ireland for 15 years.

Do migrations have an impact on families and their members? This is the question that the respondents were eager to answer, pointing to different cultural conditions of Poles and Irish people. In the opinion of the respondents (practically all of them), migrations had a big impact on their and their families' lives. The respondents claimed that people who did not get married in Poland or do not meet with another Pole or a Pole have difficulties. Marriages happen, but rarely. One of the respondents, Wojciech, stated that: "There was a case in my family that Bartek, a bachelor, came to live with us and met a Polish woman in Ballyjamesduff who had no husband but had a child with another. They got married and have a family."

Unfortunately, many families have fallen apart through migration, Jerzy states, because [Poles] come to Ireland, get to know new people, new habits, culture, freedom, and knowing this, they find that they are better off, or are looking for happiness with another person - there were several such cases in Ballyjamesduff. One couple came for a year or two to earn money for the wedding - the wedding didn't 
happen, he was at work and she was with another man at their house. Now everyone lives in a different mixed, international relationship.

The separation from loved ones negatively affects single fathers in Ireland. Polish fathers write letters, miss, call, send money and go to Poland, but travelling is difficult due to the cost of the flight, the cost of transport to the airport, transfer from the airport to their place of residence in Poland. Although the plane is relatively fast (about 3 hours of the flight itself), prices of tickets to invite the family for holidays to Ireland are high, the cost of sightseeing has also increased. One of the respondents described contemporary migrants with such words: The Irish Tiger is gone ... those who came here between 2004-2008 made some extra money, put them away, stayed to live here permanently or to retire. The rest of them come back home, where they build houses in Poland, buy flats, renovate their parents' homes and there they bind their future. It is noticed that more and more families and single parents (wives in Poland) do so. More and more people are coming to Poland - from Ballyjamesduff and Virginia a lot of people have already permanently gone to Poland. where the financial situation is getting better, but that is not all - no one but money paid attention to the health of the people working here - we can not afford treatment and medical care. It's expensive here. People have worked, put off, invested and return to heal and repair their own health while waiting for retirement or benefits.

When asked about the roles of members of migrant families as well as their functions, the respondents were conservative in their statements. Generally speaking, they stated briefly that families in Ireland, taking into account their own experiences as well as observations, have the same roles as in Poland. At the beginning of their stay in Ireland, women generally did not work, they looked after their children, husbands and the households; they could "earn some extra money, but did not have to." Nowadays, the situation is similar with a greater emphasis on the expression of "extra money" due to greater financial expenses related to maintaining the family. In general, life in Ireland is becoming more and more expensive (in Poland also). Family income in Ireland has improved slightly due to wage increases since 2004, but Poles in Ireland are now putting away relatively less than in 2004-2008. The standard of living in Ireland is decent, but in Poland it is changing in favour of Poland. Ireland from 2004 to 2008 was a country where the standard of living in relation to the costs of living was high, while since 2009 the price of living in this country has been increasing. An example is the price of at least some products, such as bread, which in 2005 cost 0.49 euro and in 20191.50 euro. There has been an increase in the price of goods and services compared to that from 15 years ago. ${ }^{21}$

${ }^{21}$ Household Finance and Consumption Survey 2018 (press statement), https://www.cso.ie/en/ csolatestnews/pressreleases/2020pressreleases/pressstatementhouseholdfinanceandconsumptionsurvey2018 [accessed 30 January 2020]. 
In Ireland, Polish families are noticed by other nationalities, and valued for several reasons. First of all, Polish homes are generally neat and tidy - the house is in order, tidy and the hand of the "housekeeper" is visible because it is cooked, sometimes baked and somehow so normal - Irish Poles envy Poles. Once it was even joked about Poles living in Ireland (the author talked to postmen, teachers or a priest in Ireland), who expressed favourable opinions about Polish families and children confirming the above described examples. As a rule, men work hard, usually physically, so they spend a lot of time away from home. However, as one of the respondents said, the longest living in Ireland since 2004 of all those participating in the survey: you have to work everywhere, work a lot if you want to earn money and have something - in Poland too.

\section{THREATS TO MIGRANT FAMILIES}

Respondents were asked about the factors that unite or separate Polish families in Ireland. Practically all respondents unanimously pointed out to such factors that bind Poles together as values, nation, culture, language, the Church, Polish pastoral ministry, Polish rituals, Polish language at weekend schools, native products in shops and many Polish shops in different cities. Joint festivals, Polish accents in schools and parades are also important (even the 17th March - St Patrick's Day of the patron saint of Ireland). The family unites the cultural canon from which Poles come, especially the respondents who mostly came from Lesser Poland and the region of Podkarpackie emphasize regionalism, culture, religiousness and tradition, pointing out to such elements of their lives as a pastoral visit. In addition, separation in the case of split families kills love, closeness, is far away and the Internet is not a substitute for live conversations, hugs or even quarrels. Despite all this, the respondents indicate that they watch Polish TV stations, read news on Polish internet portals, also follow the fate of the countrymen in Ireland - they are happy that someone from Poland has succeeded in Ireland - Poles are visible and Poles are known in a positive sense not like in the case of other non-Irish nationalities (Ukrainians, Lithuanians or Bulgarians). Stress and loneliness break families up the respondents stated that it is impossible to get in a car and drive home like in Germany - the respondents are of the opinion that in countries such as Germany, Belgium, the Netherlands, France Poles have more opportunities to move to their country of origin.

Poles, however, lack family warmth - that's what all respondents from families temporarily disconnected answered. One of the men said:

Once there was a lack of bread, products, dishes,now we have it in abundance - our stores are - the POLONEZ store in Virginia, Polish Store in Bally, or the Ruski store in 
Bally. You can buy everything. Besides, there is the internet - in 2004 it wasn't there, there are smartphones and Facebook - it wasn't there once ... life is easier, but on the other hand the stress and emptiness remain. I have a small daughter, who is 3 years old, adult son and a daughter in her 2nd year of studies. I miss... I miss it to look at them live and not on the phone.

The respondents showed that the situation of Polish families in Ireland is rather good. Despite the fact that Poland's economic situation is getting better and better, the ones in power recognize the problems of people who had to go abroad for various reasons. The situation is still not determined well enough to make Poland a country of a peaceful existence. During their stays in the homeland (holidays, festivities, family celebrations, business appointments) migrants notice also the high prices of products, food, fuel and services. At this point one of the women, a Ballyjames grocery store shop assistant, should be quoted:

When I come to Poland I can see how much I can buy for the proverbial hundred - 10 years ago a full shopping basket, 5 years ago two bags and now almost nothing ... life in Poland is very expensive, but the state gives something ... it doesn't give enough to equalise the opportunities and lost time. After all, we will never catch up with the West. Comparing the Irish to the Poles as a nation, there is a fundamental difference: the Irish draw from the West and the America they went to - there they developed and brought capital to pursue their goals in Ireland. We Poles have drawn for too long from the East (USSR) and Germany ... These are probably not good examples to follow.

Therefore, the situation of families in Poland is getting better but it is not the best. In Ireland, Polish families have good conditions for development. If someone shows willingness, diligence, and ambitions, in Ireland he will educate children, send them to school, learn a language or a profession appropriate to their interests. However, there is a considerable group of Poles who decided to return. These are usually married people, singles (change of emigration country) who leave, while Polish families living in Ireland, who bought homes and send their children to schools are likely to stay in this country. Respondents therefore saw a different problem - the issue of burials of Poles in Ireland, preceded be death of the elderly (grandparents) or middle-aged individuals who die of various causes. A large group of people decide to transport the body or ashes to Poland - however, services are ordered in Irish churches, where pastoral care of Polish priests is provided. The respondents agree that in Ireland, despite the fact that Poles are valued as professionals, they are always strangers from a different cultural background, which can be noted, e.g. in terms of schools' access for Polish children. Besides, medical care is hampered by quality of service, prices, mental and lan- 
guage barriers, which are decreasing but still exist. Many people educated children in Poland (studies), built houses, bought flats ... in the country they would not achieve this. One of the respondents, a middle-aged man, living far away from his nearest and dearest, said:

The situation is different for people like me - I have a family in Poland, I have my new home, a plot, children and property - now I can manage it in Poland and I have no loans ... and if someone does not have it in Poland and would have to start immediately - better to start with better conditions, i.e. in Ireland, and focus on life in this country. There is higher quality of medical services in Poland, education is better.

To conclude, it should be stated that despite the passage of time since 2004, Poles still do not feel "at home" in Ireland, it is not easy for them to find themselves in a new cultural or social situation, but they manage. By fighting for their rights, for example at children's schools, at work or on the street. The Irish as a nation welcomed Poles eagerly and appreciated their talents and dexterity. At present, respondents were very negative about the large number of migrants of Ukrainian, Romanian or Bulgarian origin.

There are still barriers and communication difficulties - the situation is much better than 10 years ago, misunderstanding of the language, regionalism or Irish is still noticeable. In addition, Polish people working in Ireland create small enclaves, often meet in circles of Polish origin friends. Poles also notice soaring prices of flats and houses, both when buying and renting. Therefore, it was noted that despite the large number of empty houses that were built between 2004 and 2008, no one inhabits them due to the seizure by the bank. The property was taken from users owing to unpaid banking liabilities. The properties are deteriorating while foreigners are trying hard to rent a room or a house, which is not an easy task - at least in the places where the research was conducted.

We have a high standard of living, but the cost of this standard is even higher. After all, I have to assess life here positively, in Poland I have a car, I have a car here, we manage, but the pain and longing remain. And that rain and winds.

\section{CONCLUSION}

The conclusions of the research, despite the low number of interviews due to time barriers, are interesting and indicate further in-depth research in this area. Migrant families from Poland living in Ireland prefer to function in groups and full families, fearing their disintegration due to the disappearance of family ties between individual family members, especially spouses, as well as the departing spouse and 
his children in the case of temporarily separated families. Besides, the distance between Poland and Ireland does not facilitate movement between these countries due to the cost and time needed for travel. Irish and Polish people are nations with one common denominator - the value of the family as a basic unit of society despite changes in awareness - and thus facilitates the implementation of family functions, which can be seen for example in the case of family support in Ireland as well as in Poland (especially now after 2015). Initially, Ireland was for migrants from Poland the "migratory El Dorado," one over the years, especially after 2009, when the effects of the economic crisis were felt, the situation changed slightly, although it did not deteriorate drastically. State aid has changed and its forms have changed, but Ireland is still a family friendly country. Polish families, regardless of whether both of the spouses work or not - are characterized by economy, hospitality and the way of spending free time together with the loved ones and friends at their homes rather than in the city or gastronomic premises or public facilities.

\section{BIBLIOGRAPHY}

About Us, http://irishpolishsociety.ie/about-us/ (see: February 24, 2020).

BobeK Alicja, Polscy migranci w Irlandii. Rola sieci społecznych w procesie migracyjnym oraz w kształtowaniu się społeczności etnicznej, "Studia Humanistyczne AGH," Vol. 8, 2010, pp. 57-67.

Castles Stephen, Hein de HaAs, Mark J. Miller, The Age of Migration International Population Movements in the Modern World Fifth Edition, London: Published by Palgrave Macmillan, 2014.

CÉAD Míle FÁILTE, Ireland in Brief. A general overview of Ireland's political, economic and cultural life, Iveagh House, headquarters of the Department of Foreign Affairs and Trade, Dublin 2013.

Central Statistics Office, Census 2016 - Non-Irish Nationalities Living in Ireland, Marital Status, https://www.cso.ie/en/releasesandpublications/ep/p-cpnin/cpnin/polish (see: February 28, 2020).

Central Statistics Office, Census 2016 Profile 7 Migration and Diversity, Press Statement, Preasráiteas 21 September 2017 (see: February 20, 2020).

Central Statistics Office, Household Finance and Consumption Survey (HFCS) 2018, Press Statement Preasráiteas 30 January 2020 (see: February 20, 2020).

Central Statistics Office, Ten nationalities account for $70 \%$ of Non-Irish Nationals, Press Statement, Preasráiteas 18 September 2018 (see: February 19, 2020).

FaIst Thomas, The Volume and Dynamics of International Migration and Transnational Social Spaces, Oxford: Clarendon Press 2000.

Hoffman Steven, Ireland and Poland: A History of Solidarity, www.krakowpost.com/ 8908/2015/03/ireland-and-poland-a-history-of-solidarity (see: March 17, 2015). 
KLIMEK Łukasz, Migration and Fertility. Polish Migrant Families in Ireland and Non-Migrant Families in Poland A Comparison of Fertility Plans and Behaviour, "Central and Eastern European Migration Review," Vol. 6, No. 2, 2017, Published online: 18 October 2017, pp. 5-30.

LeE Everett S., A Theory of migration, “Demography,” Vol. 3, 1966, pp. 47-57.

Lisenkova Katerina, Mosca Irene, Wright Robert E., Ireland and Scotland: Converging or Diverging Demography?, "Scottish Affairs," Vol. 64, No. 1, 2008, pp. 18-36.

Łukasiuk Magdalena, Jedokimow Marcin, Niedom. Socjologiczna monografia mieszkań migracyjnych, Warszawa: Wydawnictwo Akademickie Żak 2012.

ŁuKASIUK MARCIN, Obcy w mieście. Migracja do współczesnej Warszawy, Warszawa: Wydawnictwo Akademickie Żak 2007.

MícheÁl ua SÉAghdHA, The Story of Ireland a Bridge Between Celtic and Modern, America and Europe, Prague: Published by: Nakladatelství Bridge(C), Bridge Polska 2007, pp. $22-30$.

O'CARroll Sinead, Polish families reuniting in Ireland as they become largest non-Irish grouphttps, ://www.thejournal.ie/polish-families-reuniting-in-ireland-as-they-becomelargest-non-irish-group-400769-Mar2012/ (see: February 28, 2020).

Praszalowicz Dorota, Polskie studia na temat migracji kobiet: wybrane perspektywy teoretyczne i wyniki badań, in: Migracje kobiet. Perspektywa wielowymiarowa, ed. K. Slany, Kraków: Wydawnictwo Uniwersytetu Jagiellońskiego 2008, pp. 51-62.

Press Statement Household Finance and Consumption Survey 2018, https:/www.cso.ie/ en/csolatestnews/pressreleases/2020pressreleases/pressstatementhouseholdfinanceandconsumptionsurvey2018/30 January 2020 (see: February 28, 2020).

Ravenstein Ernst Georg, The Laws of Migration, "Journal of the Statistical Society of London," Vol. 48, No. 2, 1885.

Richmond Anthony H., Immigration and Structural Change: The Canadian Experience, 1971-1986, “International Migration Review,” Vol. 26, No. 4, 1992, pp. 1200-1221.

White Anne, Polish Circular Migration and Marginality: A Livelihood Strategy Approach, “Studia Migracyjne - Przegląd Polonijny,” Vol. 1, 2016, pp. 151-164.

\section{THE CONTEMPORARY MIGRANT FAMILY IN THE EYES OF A POLE IN IRELAND}

\section{Summary}

On the basis of contemporary socio-economic transformations, especially after Poland's accession to the structures of the European Union on May 1, 2004, there was a rapid outflow of Poles to EU countries, with particular emphasis on Great Britain and Ireland. It is estimated that currently about 120,000 Polish citizens reside in Ireland. They create families there, live alone or function in temporarily separated families. The aim of the article is to show, on the basis of pilot studies - free-form interviews, the essence of a modern migrant family, with particular em- 
phasis on relationships between family members, their social roles, the implementation of family functions as part of a broadly understood migration and adaptation to new living conditions of migrants. Respondents were also asked about the issue of traditional and modern forms of marrital and family life as well as about the impact of migration on the breakdown of families or the disappearance of traditional family forms, which are being replaced with alternative forms.

Keywords: contemporary migration; family migration; Poles in Ireland

\section{WSPÓŁCZESNA RODZINA IMIGRANTÓW W IRLANDII OKIEM POLAKA}

\section{Streszczenie}

Na kanwie współczesnych przeobrażeń społeczno-gospodarczych, zwłaszcza po przystąpieniu Polski do struktur Unii Europejskiej 1 maja 2004 r., nastąpił gwałtowny odpływ Polaków do krajów unijnych, ze szczególnym uwzględnieniem Wielkiej Brytanii i Irlandii. Szacuje się, iż obecnie w Irlandii przebywa około 120 tysięcy obywateli polskich, którzy tworzą tam rodziny, żyją samotnie lub funkcjonują w rodzinach czasowo rozłączonych. Celem artykułu jest ukazanie na podstawie badań pilotażowych: wywiadów swobodnych, istoty współczesnej rodziny migracyjnej, ze szczególnym uwzględnieniem więzi pomiędzy członkami rodzin, ról społecznych członków rodzin, realizacji funkcji rodzinnych w ramach szeroko ujętej migracji i dostosowania do nowych warunków życia migrantów. Respondenci zostali zapytani o kwestię tradycyjnych oraz nowoczesnych form życia małżeńsko-rodzinnego. Zapytano także o wpływ migracji na rozpad rodzin lub zanik ich tradycyjnych form, zastępując je alternatywnymi.

Słowa kluczowe: migracje współczesne; rodzina migracyjna; Polacy w Irlandii 